\author{
Jurnal Pendidikan Dasar Indonesia is licensed under \\ A Creative Commons Attribution-Non Commercial 4.0 International License
}

\title{
Keteladanan Guru sebagai Sarana Penerapan Pendidikan Karakter Siswa
}

\author{
Deni sutisna $^{1)}$, Dyah Indraswati ${ }^{2)}$, Muhammad Sobri ${ }^{3)}$ \\ ${ }^{1)}$ Universitas Mataram, NTB \\ Email: denisutisna@unram.ac.id \\ ${ }^{2)}$ Universitas Mataram, NTB \\ Email:dyahindrawati@unram.ac.id \\ ${ }^{3)}$ Universitas Mataram, NTB \\ Email:muhammad.sobri@unram.ac.id
}

\begin{abstract}
Abstrak. Penerapan Pendidikan karakter merupakan sebuah jalan untuk membangun pendidikan yang lebih bermoral. Penulisan artikel ini bertujuan untuk mengkaji dan menganalisis keteladanan guru dalam penerapan pendidikan karakter disekolah. Artikel ini merupakan hasil analisis dengan mengkaji literatur yang memiliki keterkaitan dengan topik pembahasan. Model yang digunakan adalah studi literatur atau lirature riview. Dari hasil penelaahan, hasil yang didapat menunjukkah bahwa penerapan pendidikan karakter disekolah merupakan tanggung jawab semua warga sekolah, tetapi guru memegang peranan penting dalam pencapaian program tersebut sehingga dapat ditarik kesimpulan bahwa keberhasilan pendidikan karakter disekolah bergantung dari sejauh mana guru tersebut bisa menjadi teladan siswa-siswinya sehingga untuk mewujudkan siswa yang berkarakter diperlukan guru yang berkarakter pula.
\end{abstract}

Kata Kunci: Keteladanan Guru dan Karakter

\section{PENDAHULUAN}

Guru itu digugu dan ditiru. Sebuah ungkapan lama yang merupakan sebuah keharusan. Simpel memang, tapi implikasi dari sebuah ungkapan yang sangat tidak mudah untuk di terapkan. Guru memang merupakan ujung tombak pendidikan, dimana salah satu keberhasilan dari pendidikan adalah sejauh mana tingkat kredibilitas seorang guru dalam artian seprofesional apa guru tersebut. Menurut referensi [1] guru profesional adalah guru yang ahli dibidangnya dan memiliki standar dengan memiliki landasan pengetahuan,memiliki kompetensi, memilik sertifikasi, berkompetisi sehat, memiliki kesadaran profesional, memiliki kode etik, dan memiliki organisasi profesi. Sementara menurut Undang-Undang No. 14 tahun 2015 pasal 10 ayat 1tentang guru dan dosen dimana guru harus memiliki kompetensi pedagogik, kepribadian, sosial, dan profesional. Sebagaimana kita tahu tugas guru tidaklah mudah, bukan hanya sekedar membuat siswa menjadi pintar, bukan hanya sekedar mengajari membaca dan menulis, bukan pula sekedar menjadikan siswa yang ahli dalam matematika dan sains tetapi lebih dari itu guru harus bisa menjadi role model untuk para siswanya yang bisa menumbuhkan nilai-nilai karakter yang baik. Keberhasilan guru bukan hanya sekedar sejauh mana keahlian dalam mengajar, seberapa banyak kompetensi yang dia miliki tetapi lebih kepada sejauh apa guru bisa menjadi panutan bagi siswa-siswinya yang nantinya bisa menjadi guru yang diguru dan ditiru. Masalah guru adalah masalah pendidikan, karena keberhasilan guru adalah keberhasilan sistem pendidikan karena [2] menegaskan bahwa guru harus bisa berperan dan bersikap selaras dengan keinginan dan kebutuhan masyarakat.

Sebagai negara berkembang, Indonesia menghadapi permasalahan yang cukup kompleks dalam dunia pendidikan. Permasalahan tersebut datang dari berbagai aspek, seperti permasalahan siswa, permasalahan guru, permasalahan sekolah, permasalahan lingkungan luar sekolah yang berdampak kepada lingkungan sekolah, kurikulum, dan kebijakan-kebijakan pemerintah dalam bidang pendidikan. Seperti yang dikemukakan oleh referensi [3] bahwa pendidikan memiliki masalah yang sangat dasar dan dapat dilihat dari faktor: pertama, proses pembelajaran terlalu berorientasi pada penguasaan teori dan hafalan yang menyebabkan kurang berkembangnya penalaran peserta didik 
dalam pembelajaran; kedua, tuntutan kurikulum yang terstruktur dan membebankan sehingga menyebabkan pembelajaran kurang bisa beradaptasi dengan lingkungan baik fisik ataupun sosial, ketiga, kurangnya monitoring terhadap penilaian dan pengujian mutu pendidikan; keempat, bimbingan karier seorang guru masihbelum tertata dengan optimal. Selain kajian diatas yang menjadi fokus masalah pendidikan di Indonesia saat ini adalah tentang karakter siswa atau peserta didik.

Berbicara terkait karakter artinya berbicara tentang kecenderungan seseorang untuk bersikap dan mencerminkan diri dan berbicara tentang karakter siswa artinya berbicara terkait dengan bagaimana cara siswa tersebut dalam bertindak, bergaul, berkomunikasi, bertatakrama dalam berinteraksi baik dengan teman, orang tua, guru, atau dengan lingkungannya. Permasalahan karakter telah menjadi topik yang hangat diperbincangkan. Krisis karakter adalah krisis kepribadian, buruknya kepribadian berdampak pada penyimpanganpenyimpangan sosial.

Permasalahan karakter merupakan permasalahan inti dari seorang siswa. Meski karakter dibentuk sebagian besar dalam keluarga tetapi lingkungan dan sekolah menjadi faktor pembentukan dan perubahan karakter tersebut. Sebagai motor penggerak sekolah, Guru tentunya memegang peranan penting dalam pembentukan karakter siswa. Seyogianya guru harus dapatmenganalisis karakter siswa baik yang terlihat (character as seen) ataupun karakter yang bisa dialami (character as experienced) [4], dengan demikian guru dapat lebih mengendalikan dan memahami karakteristik yang nantinya akan dengan mudah memberikan pemahaman dan pandangan yang baik bagi perkembangan karakter siswa.

Keberhasilan pendidikan karakter di sekolah terletak pada sejauh mana keberhasilan guru dalam mengelola kelas. Penanaman karakter bukan hanya sebatas materi baik yang tertulis ataupun yang tidak tertulis dalam kurikulum pendidikan, akan tetapi perlu contoh nyata bagi seorang siswa tentang bagaimana penerapan karakter yang baik. Dalam hal ini gurulah yang harus bisa menjadi panutan, menjadi contoh, menjadi cerminan tentang bagaimana karakter yang sesungguhnya dalam artian seorang guru harus memiliki keterampilan sesuai bidangnya, berwawasan luas yang bisa di transferkan kepada siswanya, dan memiliki sikap dan kepribadian yang pantas menjadi teladan yang sesuai dengan nilai dan norma yang berlaku pada masyarakat[5].

Paparan di atas menunjukkan bahwa guru menjadi aktor utama dalam keberhasilan pendidikan karakter disekolah. Tidak hanya seorang pendidik, pengajar, pentransfer, penganalisis, penilai, pemberi motivasi, pengembang inovasi dan pemberi inspirasi, lebih dari itu guru harus menjadi teladan demi keberhasilan pendidikan karakter disekolah. Analisis ini mencoba mengkaji nilai-nilai keteladanan guru sebagai sarana pengembangan karakter siswa SD disekolah.

\section{METODE PENELITIAN}

Artikel ini menggunakan studi literatur atau literature riview dengan menganalisis beberapa kajian yang berkaitan dengan topik pembahasan yaitu pendidikan, keteladanan guru, dan karakter. Sumber-sumber rujukan yang menjadi pokok bahasan bersumber dari buku, jurnal artikel, prosiding dan yang lainnya. hal tersebut dimaksudkan untuk meninjau keteladanan guru sebagai sarana penerapanpendidikankarakter siswa di sekolah.

\section{HASIL DAN PEMBAHASAN}

\section{Karakter}

Karakter merupakan kecenderungan yang dimiliki manusia dalam bertindak, bersosialisasi, berinteraksi dengan lingkungan baik fisik ataupun sosial. Karakter merupakan hal paling mendasar dalam menentukan pencapaian hidup karena karakter bisa menjadi dorongan untuk hal yang dianggap baik untuk hidup [6]. Setiap manusia terlahir dengan karakteristik yang berbeda dengan latarbelakang yang berbeda pula baik latar belakang suku, agama, ras, dan adat istiadat. Perbedaan tersebut bisa menjadi faktor penyebab perbedaan kebiasaan. Perbedaan kebiasaan akan berpengaruh kepada kepribadian dan tentunya akan menyebabkan perbedaan karakter. Pada dasarnya karakter terbentuk dari keturunan dan lingkungan, akan tetapi lingkungan berperan besar dalam pengembangan karakter yang dimiliki manusia baik lingkungan keluarga, lingkungan pertemanan, lingkungan kerja, atau lingkungan pendidikan tetapi yang paling dominan dalam pembentukan karakter adalah lingkungan keluarga.

Karakter erat kaitannya dengan kepribadian. Kepribadian adalah dorongan dalam diri yang mengatur dan memberikan arah hidup yang diinginkan.Referensi [7] menjelaskan kepribadian didapat manusia dari lahir yang merupakan karakter bawaan atau genetik yang melekat pada individu dan memungkinkan untuk berubah meski secara lambat Dari segi ilmu psikologi, kepribadian merupakan kualitas seseorang yang menyebabkan rasa senang atau tidak dari orang lain [8]. Teori diatas menunjukkan bahwa karakter merupakan hasil dari kepribadian yang berkembang selama manusia itu hidup. hal-hal yang menjadi ciri kepribadian adalah: 1). kepribadian berasal dari diri sendiri sebagai seorang individu, 2). Menggambarkan perilaku dalam menghadapi berbagai situasi, 3). Bersifat tahan lama,dalam artian tidak mudah berubah dalam jangka waktu yang pendek, 4). Menjadi pembeda individu dengan individu lain [9].

Karakter adalah kecenderungan manusia dalam bertindak yang terbentuk dari pengalaman semasa manusia hidup dari mulai dilahirkan hingga dewasa. George herberd maid mengemukakan Ada empat tahapan pembentukan kepribadian yang erat kaintaanya dengan pembentukan karakter seorang manusia yaitu tahap persiapan (preepatory stage), tahap meniru (play stage), tahap bermain peran (game stage), tahap penerimaan dan penerapan nilai dan norma (generalized other). Tahapan tersebut merupakan fase-fase 
ideal manusia dalam mengembangkan karakter. Karakter akan terbentuk dan berubah sesuai dengan lingkungan dimana manusia tersebut hidup dan menjalani kehidupan.

Seperti yang telah dibahas di atas bahwa karakter berkembang selama manusia itu hidup. Setiap detik, menit dari waktu yang telah kita habiskan dalam hidup akan membentuk karakteristik yang berbeda dengan individu lain.

Setiap anak yang lahir dalam sebuah keluarga akan diajarkan kebiasaan-kebiasaan sesuai dengan kebiasaan keluarganya. Baik atau buruk karakter seorang anak itu tergantung dari kebiasaan keluarganya. Pendidikan nilai, norma, dan kebiasaan pertama kali didapat dari keluarga oleh karena itu keluarga merupakan dasar utama dalam mengajarkan dan menerapkan karakter setelah itu baru lingkungan lainnya yang dapat mempengaruhi karakter seorang anak.

Penerapan pendidikan karakter perlu ada sinergitas dari beberapa faktor baik dari keluarga, lembaga pendidikan ataupun lembaga pemerintah. Terkait dengan porsi dari aspek tersebut, keluarga tentu memiliki tempat paling besar. Meski demikian, pemerintah terus berusaha untuk menumbuhkan karakter siswa dengan jalan pendidikan. Pendidikan karakter di sekolah semata-mata untuk menumbuhkan dan mengembangkan karakteristik siswa yang lebih berkualitas, berdaya saing, dan berakhlak mulia dan dimaksudkan untuk menciptakan manusia Indonesia yang cerdas, demokratis, dan berperadaban [10]

\section{Tujuan dan PrinsipPendidikan Karakter}

Pendidikan karakter adalah suatu proses pembelajaran yang mendukung perkembangan sosial emosional dan etis siswa dan sebuah upaya untuk membangun karakter [11]. Pendidikan karakter bertujuan untuk membentuk pribadi yang beriman dan bertakwa yang lebih bertanggung jawab atas segala perilaku yang dimiliki oleh siswa, termasuk didalamnya rasa percaya diri, bertanggung jawab, kompetitif, inovatif, kreatif, murah hati, berjiwa besar, baik hati, jujur, lapang dada, berjiwa sosial yang tinggi dsb.Secara teoritis ada tiga tujuan utama dari pendidikan karakter menurut [12] yaitu: untuk membentuk dan mengembangkan profesi, memperbaiki dan menguatkan pribadi, menyaring dan memilah kebudayaan dan peradaban yang berkembang. Untuk mewujudkan semua itu diperlukan prinsip-prinsip demi mewujudkan keberhasilan pendidikan karakter disekolah.

Ada sebelas prinsip yang bisa dijadikan penunjang keberhasilan pendidikan karakter menurut Thomas lickona dalam [10] yaitu: 1) komunitas sekolah mengembangkan nilai-nilai etika dan kemampuan inti sebagai landasan karakter yang baik, 2). sekolah mendefinisikan karakter secara komprehensif untuk memasukkan pemikiran, perasaan, dan perbuatan, 3). Sekolah menggunakan pendekatan komprehensif, sengaja, dan proaktif untuk mengembangkan karakter, 4) sekolah menciptakan masyarakat peduli karakter, 5).sekolah memerikan kesempatan kepada peserta didik untuk melalukan tindakan moral, 6) sekolah menawarkan kurikulum akademik yang berarti menantang yang menghargai semua peserta didik mengembangkan karakter, dan membantu mereka untuk mencapai keberhasilan, 7). Sekolah mengembangkan motivasi diri peserta didik, 8) staf sekolah adalah masyarakat belajar etika yang membagi tanggung jawab untuk melaksanakan pendidikan karakter danmemasukkan nilai-nilai inti yang mengarahkan peserta didik, 9). Sekolah mengembangkan kepemimpinan bersama dan dukungan yang besar terhadap permulaan atau perbaikan pendidikan karakter, 10). Sekolah melibatkan anggota keluarga dan masyarakat sebagai mitra dan upaya pembangunan karakter, 11). Sekolah secara teratur menilai dan mengukur budaya dan iklim fungsi-fungsi staf sebagai pendidik karakter serta sejauh mana peserta didik mampu mengimplementasikankarakter yang baik dalam pergaulan sehari-hari . ada keterkaitan antara satu aspek dengan aspek lainnya dari penjelasan, dimana 11 faktor diatas merupakan satu kesatuan yang tidak bisa terpisahkan dalam proses penerapan pendidikan karakter di sekolah.

\section{Implementasi Pendidikan Karakter di Sekolah}

Pada dasarnya penerapan pendidikan karakter dapat diimplementasikan dalam segala aspek disekolah baik kurikulum sekolah ataupun penunjang lainya seperti lingkungan, sarana prasarana, dan kebijakan. Terlebih lagi[13] menegaskan bahwa pendidikan karakter lebih menekankan kepada proses yang terintegrasi pada kurikulum sekolah. Ada empat cara yang dapat ditempuh dalam penerapan pendidikan karakter; 1) menerapkan pada setiap mata pelajaran yang ada disekolah baik mata pelajaran wajib ataupun muatan lokal; 2). Menerapkan kedalam kegiatan harian non pelajaran seperti upacara wajib, upacara hari-hari besar, acara keagamaan, dan acara yang bersifat Insidental; 3). Merencanakan dalam program sekolah jangka pendek dan jangka panjang; 4). Mensosialisasikan kepada semua elemen sekolah terutama kepada keluarga siswa [14] dengan demikian penerapan pendidikan karakter di sekolah dapat diterapkan.

Penerapan pendidikan karakter disekolah tidak lepas dari peran seluruh warga sekolah. Kepala sekolah sebagai pemangku kebijakan, guru sebagai eksekutor dari program, orang tua sebagai daya dukung di rumah, komite sekolah sebagai jembatan antara program sekolah dan orang tua memiliki peranan masing-masing dalam penerapan Pendidikan karakter.Dalam hal ini guru memiliki peran terpenting dalam penerapan pendidikan karakter disekolah karena guru yang secara langsung berinteraksi dengan siswa.

\section{Keteladanan Guru dan Pendidikan Karakter}

Keberhasilan dunia pendidikan tidak lepas dari peran guru dalam menjalankan program-program pendidikan terutama kurikulum sekolah. Kiprah seorang guru tentunya menjadi salah satu faktor yang sangan dominan dalam indikator ketercapaian pendidikan (pembelajaran) dimana guru menjadi figur utama dalam proses pembelajaran disekolah. Oleh karena itu guru harus memiliki kemampuan yang mumpuni agar dapat menjalankan tugas sebagai guruprofesional.

Guru profesional merupakan kunci dari keberhasilan pendidikan. Professional artinya ahli dibidangnya. Ciri-ciri dari profesional adalah, harus memiliki landasan pengetahuan yang kuat, harus berlandaskan atas kompetensi atas individu, 
memiliki sistem seleksi dan sertifikasi, ada kerjasama dan kompetisi yang sehat antar sejawat, adanya kesadaran profesional yang tinggi, memiliki kode etik, memiliki sistem sanksi profesi, adanya militansi individual, dan memiliki organisasi profesi C0. Hole dalam [1].

Bermodalkan keahlian seperti di uraikandiatas, seorang guru mampumenjalankan kewajibannyadan berperan sebagai fasilitator yang menyediakan kemudahan-kemudahan bagi pesertadidik dalam proses belajar mengajar, sebagai pembimbing yang membantu siswa mengatasi kesulitan pada proses pembelajaran, sebagai penyedia lingkungan yang berupaya menyediakan lingkungan belajar yang menantang bagi siswa agar mereka melakukan kegiatan belajar yang bersemangat, sebagai model yang mampu memberikan contoh yang baik kepada peserta didik agar berperilaku sesuai dengan norma yang ada dan berlaku di dunia pendidikan, sebagai motivator yang menyebarluaskan usaha-usaha pembaharuan bagi masyarakat khususnya kepada siswa, sebagai agen perkembangan kognitif yang menyebarluaskan ilmu dan teknologi kepada peserta didik dan masyarakat, dan sebagai manager yang memimpin kelompok siswa dalam kelas sehingga keberhasilan proses belajar mengajar berhasil[1].

Seperti yang kita ketahui tugas guru disekolah bukan hanya sebagai pengajar, yang lebih penting dari semua itu adalah tugas guru sebagai pendidik. Mendidik artinya mengarahkan, membangun, mengembangkan kepribadian sehingga siswa memiliki karakter yang baik. Guru sebagai pendidik harus memiliki kepedulian yang tinggi terhadap pembentukan perilaku jangka panjang atau karakter peserta didik sebagaimana yang diterapkan di dalam tujuan pendidikan nasional [15] dengan demikian guru dapat melahirkan siswa yang bukan hanya sekedar pintar saja, tetapi lebih beriman, bertakwa, dan berahlak mulia dengan kata lain guru dapat melahirkan siswa yang lebih berkarakter.

Keberhasilan penerapan pendidikan karakter disekolah tergantung dari sejauh mana implementasi dari visimisi sekolah yang berkaitan dengan penguatan karakter siswa. Instrumen yang utama dalam implementasi penerapan pendidikan karakter disekolah adalah guru. Kenapa guru? Jelas. Karena guru memiliki kesempatan untuk dapat melihat, menilai, mengevaluasi, dan mengarakan siswa kearah manapun yang mereka mau dengan tuntunan kurikulum sekolah. Oleh karena itu peran guru dalam penerapan pendidikan karakter menjadi kunci utama demi ketercapaian program tersebut.

Guru memiliki peran penting dalam penerapan pendidikan karakter disekolah, akan tetapi, tidak semua guru memiliki kemampuan tersebut. Jelas dikatakana dalam undang-undang bahwa guru harus memiliki kompetensi inti yang mencakup pedagogik, kepribadian, sosial, dan profesional sehingga guru bisa menjadi teladan yang mampu mencerminkan seorang yang pantas untuk dijadikan model dalam penerapan pendidikan karakter.

Berbicara tentang guru teladan artinya berbicara tentang kepribadian dan karakter seorang guru. Seorang guru harus bisa mencontohkan sikap atau perilaku yang baik bagi peserta didik dengan sasaran supaya peserta didik mampu mengamalkan teori-teori yang sudah diajarkan oleh gurunya [16] lebih lanjut beliau mengatakan bahwa metode keteladanan sangat penting di lakukan karena peserta didik mampu melihat secara langsung apa saja yang seharusnya dia lakukan dan secara langsung peserta didik akan meniru apaapa yang dilakukan oleh seorang guru yang mereka anggap sebagai panutan kedua setelah orang tua.

Tidak mudah untuk menjadi seorang yang teladan, akan tetapi hal tersebut mutlak dimiliki oleh seorang guru. Guru selalu menjadi sorotan siswanya, apapun yang dilakukan oleh guru akan berdampak bagi perkembangan kepribadian seorang siswa. Sehingga guru bertanggung jawab terhadap perkembangan siswa baik segi afektif, kognitif, dan psikomotor sehingga teladan yang baik merupakan cara yang ampuh dalam mewujudkan semua itu dan dalam penerapan pendidikan karakter disekolah. Ada beberapa hal dasar yang harus diperhatikan oleh guru sebagai teladan yaitu; bagaimana ia bertuturkata, bagaimana kebiasaan dia dalam bekerja, bagaimana sikap dalam pengalaman dan menghadapi kesalahan, bagaimana hubungan sosialnya, bagaimana proses berpikirnya, bagaimana perilaku, kesehatan dan gaya hidupnya [17]. Setiap performa kita dihadapan siswa akan di tiru, dampak yang akan terjadi tergantung dari kesan yang kita tampilkan kepada siswa jadi guru berahlak mulia menjadi keharusan untuk mengembangkan dan melahirkan siswa yang lebih berkarakter

\section{KESIMPULAN}

Pendidikan karakter merupakan usaha untuk mengubah dan membangun kebiasaan-kebiasaan siswa yang tadinya tidak baik menjadi baik dan yang baik menjadi lebih baik, selebihnya dari itu pendidikan karakter dimaksudkan untuk membangun siswa yang lebih beriman, bertakwa, berakhlak mulia dan lebih bertanggung jawab. Sekolah merupakan tempat yang cukup ideal setelah keluarga untuk menerapkan pendidikan karakter. Oleh karena itu guru sebagai kunci utama dalam keberhasilan pembelajaran harus dapat menjadi model atau teladan bagi siswa.

Keberhasilan pendidikan karakter disekolah bergantung penuh pada bagaimana cara guru mengelola kelas. Guru adalah panutan, guru adalah sorotan sehingga apapun yang dilakukan oleh guru berdampak bagi perkembangan siswa. Oleh karena itu keteladanan guru merupakan cara terbaik dalam proses penerapan pendidikan karakter disekolah.

Hendaklah setiap guru bisa menjadi guru yang lebih profesional dalam artian guru bukan hanya sebagai profesi tetapi benar-benar panggilan hati untuk mendidik dan membimbing siswa menjadi lebih baik sehingga guru bisa menjadi figur untuk membangun siswa yang lebih berkarakter.

\section{DAFTAR PUSTAKA}

[1] Jakarta: Prenada Media Grup.

[2] Koesoema, D. (2006). Pendidik Karakter (di zaman keblinger) Mengembangkan Visi Guru Sebagai Pelaku Perubahan dan pendidik. 
[3] Ace Suryadi, D. B. (2004). Pendidikan Nasional Menuju Masyarakat Indonesia Baru. Bandung: PT Genesindo.

[4] Kesuma, D. (2007). Pendidikan Karakter (Strategi Pendidikan Anak DI ZamanGlobalisasi). Jakarta: PR Grasindo.

[5] Budimanjaya, W. S. (2017). Paradigma Baru Mengajar. Jakarta: Prenada Media Group.

[6] Rosidatun. (2018). Model Implementasi Pendidikan Karakter. Gresik: Caremedia Communication.

[7] Agus Wijaya, N. P. (2015). Kepemimpinan Berkarakter. Surabaya : Brilian Internasional.

[8] Sunaryo. (2004). Psikologi. Jakarta: Penerbit Buku Kedokteran EGC.

[9] Parkinson, M. (2004). Personality Questionnaires (memahami Kuesioner Kepribadian. Solo: PT Tiga Serangkai Pustaka Mandiri.

[10]Yaumi, M. (2016). Pendidikan Karakter (landasan, Pilar, Dan Impelmentasi). Jakarta: Prenada Mesdia Group.

[11]Nuraini, A. (2014). Pendidikan Karakter Untuk Mahasiswa PGSD. Bandung: UPI PRESS.

[12]Nuh, M. (2019, Agustus 30). Desain Induk Pendidikan Karakter. Retrieved from pendikar.dikti.go.id.: pendikar.dikti.go.id.gdp/wpcontain/upload/desain-induk-pendidikan-karakter-kemdiknas,pdf

[13] Wahyunianto, S. (2019). Implementasi Pembiasaan Diri dan Pendidikan Karakter. Sleman: CV Budi Utama.

[14]Zulhijrah, Implementasi Pendidikan Karakter Di Sekolah. TADRIB (Jurnal Pendidikan Islam), 10,2015.

[15] Susanto, A. (2018). Bimbingan Dan Konseling di Sekolah (konsep, teori dan aplikasinya). Jakarta: Prenada Media Goup.

[16]Cece Abdulwaly, F. J. (2016). Mendidik Dengan Teladan Yang Baik. Yogyakarta: Laksana.

[17]Dahlan, M. (2018). Menjadi Guru Yang Bening Hati (Strategi Mengelola Hati di Abad Modern). Yogyakarta: Penerbit Deepublish ( Group Penerbitan CV Budi Utama).Karakter. Jakarta: Grasindo. 